\title{
ANALISIS KUALITAS AIR DANAU SEBAGAI DASAR PERBAIKAN MANAJEMEN BUDIDAYA PERIKANAN DI DANAU BUYAN KABUPATEN BULELENG, PROVINSI BALI
}

\author{
I Wayan Rian Riki Saputra $\left.{ }^{1 *}\right)$, I Wayan Restu ${ }^{1)}$, Made Ayu Pratiwi ${ }^{1)}$ \\ ${ }^{1)}$ Prodi Manajemen Sumberdaya Perairan, FKP Universitas Udayana \\ "Email: wayanriki73@gmail.com
}

\begin{abstract}
Buyan Lake is one of the lakes in Bali province. That located at Pancasari Village, District of Sukasada, Buleleng Regency. This lake they are many utilication of the lake such as agriculture, tourism and aquaculture activities. Those activities are considered to contribute an eutrophication in this lake. In order to investigate the effect of of floating net cages activity in Buyan Lake, the research about "The Analysis of Water Quality as a Basic Improvement of Aquaculture Management in Buyan Lake" was conducted This research method used in this study was done by observation method and took the samples in situ (at Buyan Lake site) and samples analysis was done by ex situ (at UPT. Laboratorium Kesehatan Propinsi Bali). They were 2 water quality parameters such as some physic parameters (temperature, clarity and turbidity) and chemistry parameters ( $\mathrm{pH}, \mathrm{DO}$, ammonia, nitrate, $\mathrm{BOD}, \mathrm{COD}$, sulfide and phosphate). The data analysis of this research was analysis conducted by STORET index and pollution index (PI). Base on the analysis using STORET index, pollution status in Buyan Lake was heavily contaminated with average score of -82. The highest score was obtained in station 3 (-98). The results of pollution index showed that Buyan Lake has a lightly contamination with average score 3,4347 whereas the highest pollution index score was obtained in sation 4 (3.8673).
\end{abstract}

Keywords: Buyan Lake; Floating Net Cages; Water Quality; Physics And Chemistry Parameters

\section{PENDAHULUAN}

Danau Buyan merupakan salah satu danau di Bali yang terletak di Desa Pancasari, Kecamatan Sukasada, Kabupaten Buleleng yang memiliki banyak potensi, baik yang berbasis alam maupun peninggalan budaya yang masih terjaga keasliannya yang saat ini dikelola dalam satu manajemen konservasi Taman Wisata Alam. Taman Wisata Alam Danau Buyan dan Danau Tamblingan mencakup areal seluas 1.491,16 hektar, berlokasi di Kecamatan Banjar seluas 442,35 hektar, Kecamatan Sukasada seluas 506,3 hektar, dan Kecamatan Baturiti seluas 542,51 hektar (Badan Lingkungan Hidup Daerah Provinsi Bali, 2010). Kawasan danau buyan saat ini telah dimanfaatkan untuk berbagai keperluan masyarakat untuk kepentingan pertanian, pariwisata dan perikanan sesuai dengan sejarah masyarakat agraris di Bali yang berorientasi gunung dan laut.

Danau Buyan dimanfaatkan dalam bidang perikanan sebagai lahan budidaya ikan air tawar, yaitu dengan menggunakan sistem budidaya keramba jaring apung (KJA). Keramba jaring apung (KJA) merupakan suatu wadah pemeliharaan ikan berupa kantong jaring yang letaknya terapung di permukaan air. Komoditas utama yang dibudidayakan dalam KJA di Danau Buyan adalah komoditas ikan Nila (Oreocromis niloticus L). Secara umum tantangan yang berhubungan dengan sistem budidaya KJA yaitu terjadinya peningkatan kandungan nutrien di perairan yang berasal dari sisa pakan yang tidak termakan, dan feses ikan, serta kemungkinan dampak yang ditimbulkan terhadap kualitas perairan, lingkungan dan kondisi kesehatan ekosistem (Halwart dkk., 2007). Kartamiharja (2008) menambahkan, pada kegiatan budidaya KJA yang dilakukan di waduk yang berada di Jawa Barat teridentifikasi bahwa pakan yang terbuang ke perairan mencapai $30 \%-40 \%$.

Danau Buyan dikhawatirkan akan mengalami eutrofikasi seperti yang terjadi di danau Batur. Nastiti dkk., (2001) mengatakan bahwa perkembangan unit keramba jaring apung dan keramba jaring tancap pada areal budidaya yang kurang terkendali menimbulkan dampak negatif terhadap lingkungan perairan. Danau Buyan diduga sudah mendapat masukan zat hara yang paling tinggi dari KJA. Berdasarkan uraian tersebut maka penelitian mengenai "Analisis Kualitas Air Danau Sebagai Dasar Perbaikan Manajemen Budidaya Perikanan di Danau Buyan" perlu dilakukan penelitian untuk mengetahui status mutu kualitas air Danau Buyan akibat adanya keramba jaring apung, dalam rangka pengelolaan budidaya keramba jaring apung yang berkelanjutan. 


\section{METODOLOGI}

Pengambilan sampel dilakukan dengan cara pengambilan sampel secara sistematik yaitu pengambilan sampel yang disusun dengan lokasi sampling dibuat dengan pola yang teratur. Pengukuran kualitas air dilakukan dengan dua cara yaitu secara langsung di lokasi (in situ) dan cara pengawetan yang dilakukan di Laboratorium (ex situ), terutama untuk sifat-sifat air yang dapat bertahan lama dalam kondisi yang sudah diawetkan. Analisis secara in situ dilakukan untuk parameter kualitas air yang sifatnya cepat berubah, sehingga harus saat itu juga langsung dilakukan pengukuran. Penelitian ini telah dilaksanakan selama 3 Bulan (Januari-Maret 2016) di perairan Danau Buyan. Hasil yang telah didapat meliputi 11 parameter fisik dan kimia perairan. Parameter fisik terdiri dari suhu, kecerahan dan kekeruhan sedangkan parameter kimia yaitu $\mathrm{pH}, \mathrm{DO}$, ammonia, nitrat, BOD COD, sulfida dan phosfat. Setelah dilakukan pengukuran parameter kualitas air baik secara in situ (ukur langsung di lapangan) maupun ex situ (analisis laboratorium), dilakukan analisis mutu air dengan mempergunakan baku mutu air yang disesuaikan dengan Peraturan Pemerintah nomor 82 tahun 2001 tentang baku mutu air lingkungan hidup dan kriteria baku kerusakan lingkungan hidup menyarankan dapat dianalisis dengan metode STORET dan indeks pencemaran (IP).

\section{HASIL DAN PEMBAHASAN}

Ketersedian sumber daya air untuk suatu peruntukan sangat tergantung pada kualitas sumber daya air tersebut. Kualitas air yang baik akan mengakomodasi kegiatan usaha atau pembangunan yang lebih beragam, seperti suplai air untuk kebutuhan domestik, pertanian, perikanan, industri maupun rekreasi (Maulana, 2001). Hasil yang didapat meliputi 11 parameter fisik dan kimia perairan. Parameter fisik terdiri dari suhu, kecerahan dan kekeruhan dengan parameter kimia yaitu $\mathrm{pH}, \mathrm{DO}$, ammonia, nitrat, BOD COD, sulfida dan phosfat. Berikut merupakan hasil rata-rata pengukuran parameter fisik dan kimia perairan kualitas air di Danau Buyan (Tabel 1.).

Analisis tingkat pencemaran dengan indeks STORET dilakukan untuk mengetahui tingkat pencemaran perairan di wilayah pengamatan secara komprehensif. Penilaian dalam indeks STORET dilakukan dengan membandingkan hasil pengukuran dengan baku mutu Kelas III (PP No.82/ 2001) untuk perikanan. Skor STORET yang bernilai 0 memiliki kriteria baik sekali, sedangkan yang bernilai lebih rendah dari -1 menunjukkan adanya pencemaran. Tabel 1 merupakan hasil evaluasi berdasarkan indeks STORET.

Tingkat pencemaran di 7 stasiun yang telah dilakukan di Danau Buyan menurut indeks STORET tergolong dalam kategori tercemar berat. Semua

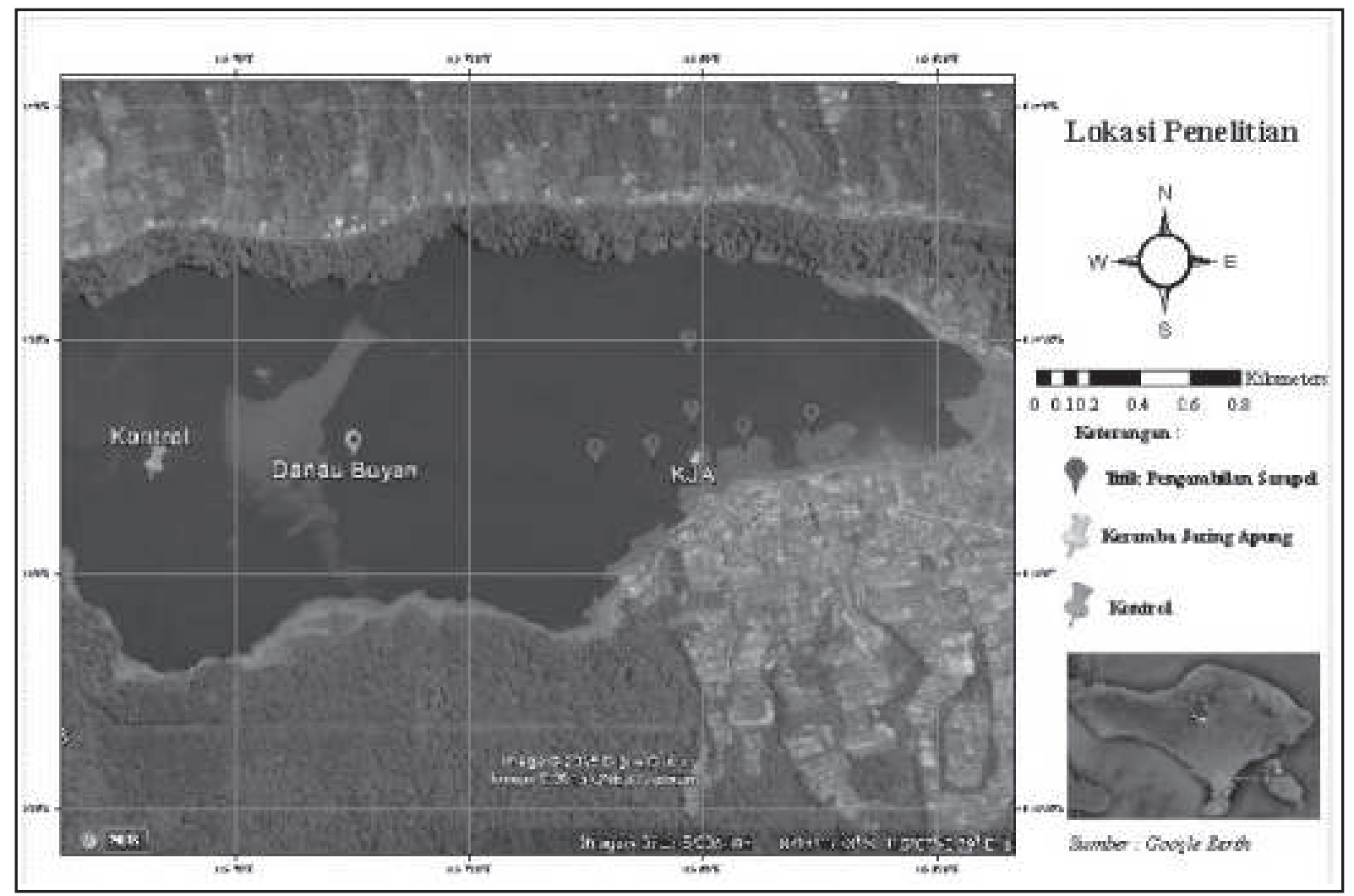

Gambar 1. Peta Lokasi Pengambilan Sampel 
Tabel 1. Rata-rata Hasil Pengukuran Kualitas Air di Danau Buyan

\begin{tabular}{|c|c|c|c|c|c|c|c|c|c|}
\hline \multirow{2}{*}{ Parameter } & \multirow{2}{*}{ Satuan } & \multicolumn{7}{|c|}{ Rata-Rata Hasil Pengukuran } & \multirow[b]{2}{*}{ Titik Kontrol } \\
\hline & & Titik 1 & Titik 2 & Titik 3 & Titik 4 & Titik 5 & Titik 6 & Titik 7 & \\
\hline Suhu & ${ }^{\circ} \mathrm{C}$ & 23.7556 & 23.7667 & 23.8000 & 24.1222 & 24.2556 & 24.4333 & 24.6222 & 24.7889 \\
\hline Kecerahan & $\mathrm{cm}$ & 209.3333 & 234.0000 & 185.8333 & 124.1667 & 136.3333 & 210.6667 & 198.0000 & 220.6667 \\
\hline Kekeruhan & NTU & 3.9344 & 4.6422 & 3.7311 & 4.0000 & 4.2211 & 3.8878 & 4.0289 & 4.3244 \\
\hline $\mathrm{pH}$ & & 8.0622 & 8.1867 & 8.2244 & 7.9924 & 8.1500 & 8.0689 & 8.1044 & 8.1689 \\
\hline DO & $\mathrm{mg} / \mathrm{l}$ & 4.0000 & 4.7000 & 4.6222 & 4.6556 & 4.4444 & 4.4778 & 4.9667 & 5.0444 \\
\hline Ammonia & $\mathrm{mg} / \mathrm{l}$ & 0.1173 & 0.0790 & 0.1013 & 0.1033 & 0.0870 & 0.0387 & 0.0783 & 0.0890 \\
\hline Nitrat & $\mathrm{mg} / \mathrm{l}$ & 0.5744 & 0.3987 & 0.3341 & 1.1433 & 0.4088 & 0.5355 & 0.5710 & 0.4662 \\
\hline $\mathrm{BOD}_{5}$ & $\mathrm{mg} / \mathrm{l}$ & 12.2000 & 28.1200 & 32.4400 & 19.1400 & 12.5067 & 8.1267 & 21.0400 & 11.9600 \\
\hline COD & $\mathrm{mg} / \mathrm{l}$ & 32.1600 & 83.9467 & 103.2000 & 54.6133 & 31.9933 & 28.6933 & 80.5333 & 35.3600 \\
\hline Sulfida & $\mathrm{mg} / \mathrm{l}$ & 0.0023 & 0.0027 & 0.0027 & 0.0037 & 0.0030 & 0.0037 & 0.0030 & 0.0063 \\
\hline Phosfat & $\mathrm{mg} / \mathrm{l}$ & 0.2217 & 0.2158 & 0.2946 & 0.2958 & 0.4739 & 0.3639 & 0.4216 & 0.2100 \\
\hline
\end{tabular}

Tabel 2. Skor Analisis Indeks STORET di Danau Buyan

\begin{tabular}{llccc}
\hline No & Lokasi & $\begin{array}{c}\text { Skor Menurut } \\
\text { Indeks STORET }\end{array}$ & Kelas & Keterangan \\
\hline 1 & Stasiun 1 & -78 & D & Tercemar Berat \\
2 & Stasiun 2 & -94 & D & Tercemar Berat \\
3 & Stasiun 3 & -98 & D & Tercemar Berat \\
4 & Stasiun 4 & -88 & D & Tercemar Berat \\
5 & Stasiun 5 & -90 & D & Tercemar Berat \\
6 & Stasiun 6 & -74 & D & Tercemar Berat \\
7 & Stasiun 7 & -94 & D & Tercemar Berat \\
8 & Stasiun Kontrol & -74 & D & Tercemar Berat \\
\hline Rata-Rata Skor & -82 & D & Tercemar Berat \\
\hline
\end{tabular}

stasiun pengamatan memiliki kriteria buruk dengan status cemaran berat dengan rata-rata skor yaitu sebesar -84. Analisis parameter kualitas air juga dilakukan dengan menggunakan metode indeks pencemaran (IP). Hasil evaluasi nilai IP kurang dari 1 menunjukkan kondisi baik, sedangkan nilai yang lebih dari -1 dikategorikan telah tercemar (Lampiran 2). Hasil evaluasi berdasarkan IP di 7 stasiun yang telah dilakukan di Danau Buyan tergolong dalam tercemar ringan. Adapun rata-rata nilai IP dari 7 stasiun pengamatan yang telah dilakukan penelitian yaitu sebesar 3.4337 (Tabel.2).
Analisis dengan Metode indeks STORET menduga status kualitas air Danau Buyan tergolong tercemar berat. Skor rata-rata yang didapat dari analisis pada semua stasiun pengamatan sebesar 82. Skor terburuk hasil Indeks STORET berada di stasiun 3 sebesar -98. Kondisi Danau Buyan yang tercemar berat didasarkan pada nilai hasil pengukuran 7 parameter kualitas air yang melebihi ambang baku mutu. Parameter tersebut diantaranya Kekeruhan (-2), pH (-4), Ammonia (-20), Nitrat (16), BOD (-20), COD (-20), dan Sulfida (-16).

Metode indeks STORET memberikan skor -2 terhadap parameter kekeruhan. Hal ini dikarenakan nilai hasil maksimum pengukuran kekeruhan di stasiun 3 sebesar 6.70 NTU (>baku mutu). Tingginya nilai kekeruhan akibat dari akumulasi partikel cemaran berbagai aktifitas di sekitar lokasi seperti partikel total suspended solid (TSS) dan total dissolve solid (TDS) pada saat pengukuran dilakukan. Jenie dan Rahayu (1993), menyatakan bahwa kekeruhan biasanya disebabkan oleh adanya bahan tersuspensi (bahan organik, mikroorganisme dan partikelpartikel cemaran lain). Derajat keasaman $(\mathrm{pH})$ di stasiun 3 memiliki skor Indeks STORET sebesar -4. Nilai maksimum hasil pengukuran $\mathrm{pH}$ di Danau Buyan sebesar 9.04 (>baku mutu). Nilai pH yang tinggi karena disebabkan besarnya logam alkali dan alkali tanah di Danau Buyan. Nilai pH yang tinggi

Tabel 3. Nilai Analisis Indeks Pencemaran di Danau Buyan

\begin{tabular}{llcccc}
\hline No & Lokasi & $\mathbf{C}_{\mathbf{i}} / \mathbf{L}_{\mathbf{i} \text { (rata-rata) }}$ & $\mathbf{C}_{\mathbf{i}} / \mathbf{L}_{\mathbf{i} \text { (maksimum) }}$ & Nilai IP & Keterangan \\
\hline 1 & Stasiun 1 & 1.5127 & 4.8413 & 3.7427 & Cemar Ringan \\
2 & Stasiun 2 & 1.7161 & 4.3543 & 3.5249 & Cemar Ringan \\
3 & Stasiun 3 & 1.8717 & 4.6646 & 3.7925 & Cemar Ringan \\
4 & Stasiun 4 & 1.8721 & 4.7857 & 3.8673 & Cemar Ringan \\
5 & Stasiun 5 & 1.4541 & 4.1924 & 3.3019 & Cemar Ringan \\
6 & Stasiun 6 & 1.2553 & 3.1386 & 2.5498 & Cemar Ringan \\
7 & Stasiun 7 & 1.7404 & 3.9637 & 3.2992 & Cemar Ringan \\
8 & Stasiun Kontrol & 1.5988 & 4.2418 & 3.3989 & Cemar Ringan \\
\hline
\end{tabular}

Rata-Rata Nilai IP $\quad 3.4347$

Cemar Ringan 
dapat meningkatkan konsentrasi ammonia dalam air yang juga bersifat toksik bagi organisme air (Kordi, 2010). Hal tersebut berbanding lurus dengan ratarata nilai ammonia di stasiun 3 yang tergolong tinggi sebesar $0.1013 \mathrm{mg} / \mathrm{l}$ (>baku mutu). Metode indeks STORET memberikan skor yaitu sebesar -20 di stasiun 3. Hal tersebut disebabkan oleh adanya proses dekomposisi bahan organik (tumbuhan) dan biota akuatik yang telah mati oleh mikroba dan jamur. Selain itu keberadaan biota akuatik khususnya ikan Nila (Oreochromis niloticus) yang dibudidayakan dengan sistem keramba jaring apung (KJA) di Danau Buyan juga ikut berkontribusi karena kotoran dari biota akuatik mengeluarkan ammonia. Sisa-sisa metabolisme atau kotoran ikan semakin banyak yang mengendap di dasar perairan tersebut sehingga terjadi kecenderungan tingginya kadar ammonia. Djosetiyanto dkk., (2006) menyatakan bahwa lebih dari 50\% buangan nitrogen ikan berupa ammonia. Kadar ammonia yang tinggi di perairan Danau Buyan juga dapat disebabkan oleh buangan limbah domestik dari penduduk sekitar. Maniagasi dkk., (2013), menyatakan bahwa tingginya kadar amoniak suatu perairan karena adanya buangan limbah domestik dari penduduk sekitarnya.

Kadar nitrat di Danau Buyan pada stasiun 3 berdasarkan hasil analisis indeks STORET memiliki skor -16. Rata-rata hasil pengukuran kadar nitrat sebesar $0.3341 \mathrm{mg} / \mathrm{l}$ (>baku mutu). Tingginya kadar nitrat disebabkan oleh sisa pakan dihasilkan oleh KJA di Danau Buyan. Ginting (2011), menyatakan bahwa input pakan pada kegiatan budidaya ikan KJA mempunyai kontribusi terhadap pengkayaan nitrat $\left(\mathrm{NO}_{3}\right)$ dalam badan air dengan koefisien determinasi sebesar 86\%. Parameter selanjutnya yang melebihi ambang baku mutu adalah Biological Oxygen Demand (BOD) dengan nilai rata-rata sebesar 32.44 mg/l. Indeks STORET memberikan skor yaitu -20 di stasiun 3. Danau Buyan seperti danau lainnya yang dimanfaatkan sebagai kegiatan perikanan, hal ini yang menjadi penyebab tingginya nilai BOD di danau tersebut. Menurut Barus (2004), nilai BOD merupakan parameter indikator pencemaran zat organik, dimana semakin tinggi angkanya semakin tinggi tingkat pencemaran bahan organik dan sebaliknya. Skor BOD yang tinggi dari indeks STORET inilah yang juga menyatakan Danau Buyan tergolong dalam status tercemar berat. Nilai BOD yang tinggi menunjukkan bahwa jumlah oksigen yang dibutuhkan oleh mikroorganisme untuk mengoksidasi bahan organik dalam air tersebut tinggi. Hal ini berarti dalam air sudah terjadi defisit oksigen. Hasil pembuangan sisa pakan KJA merupakan buangan bahan organik yang dapat membusuk atau terdegradasi oleh mikroorganisme, sehingga hal ini akan menaikkan populasi mikroorganisme di perairan. Keadaan ini akan menyebabkan meningkatnya kebutuhan oksigen terlarut yang diperlukan oleh mikroorganisme dalam mengoksidasi bahan organik.

Tingginya kadar BOD di Danau Buyan berbanding lurus dengan tingginya kadar Chemical Oxygen Deman (COD). Metode indeks STORET memberikan skor -20 di stasiun 3. Nilai COD saat penelitian di Danau Buyan pada stasiun 3 sebesar $103.20 \mathrm{mg} / \mathrm{l}$ (>baku mutu). Nilai COD yang diperoleh pada saat penelitian lebih besar daripada nilai BOD. Menurut Marganof (2007), hal ini disebabkan bahan organik yang dapat diuraikan secara kimia lebih besar dibandingkan penguraian secara biologi. Selain dimanfaatkan untuk kegiatan KJA, wilayah di sekitar Danau Buyan juga dimanfaatkan sebagai lahan pertanian. Penggunaan zat-kimia dalam aktifitas pertanian menyebabkan sisa dari zat kimia tersebut masuk ke perairan Danau Buyan. Parameter selanjutnya yang menyebabkan status kualitas air Danau Buyan tercemar berat adalah Sulfida $\left(\mathrm{H}_{2} \mathrm{~S}\right)$ dengan nilai rata-rata sebesar 0.0057 mg/l (>baku mutu). Metode indeks STORET memberikan skor -16. Walaupun tidak ada aktivitas vulkanik, keberadaan KJA dapat menyebabkan tingginya kadar $\mathrm{H}_{2} \mathrm{~S}$ yang ada di Danau Buyan. Tingginya kadar $\mathrm{H}_{2} \mathrm{~S}$ disebabkan oleh terbentuknya $\mathrm{NH}_{3}, \mathrm{H}_{2} \mathrm{~S}$ dan $\mathrm{CH}_{2}$ terbentuk dalam kondisi bahan organik tinggi dalam oksigen rendah. Sunarto (2003), menyatakan bahwa kadar $\mathrm{H}_{2} \mathrm{~S}$ disebabkan oleh beberapa faktor diantaranya yaitu perubahan $\mathrm{pH}$, nitrat, nitrit, suhu dan ammonia sebagai hasil dari proses dekomposisi yang berlangsung di perairan dimana kegiatan budidaya berlangsung.

Hasil analisis pada Indeks Pencemaran (IP) didapatkan bahwa status perairan Danau Buyan tergolong dalam kategori tercemar ringan. Hal ini berbeda dengan dengan hasil analisis indeks STORET. Perbedaan status pencemaran pada metode indeks STORET dan indeks pencemaran mungkin disebabkan oleh prinsip analisis yang berbeda. indeks STORET memiliki prinsip pendugaan nilai pencemaran berdasarkan perbandingan hasil pengukuran dengan baku mutu, sedangkan Indeks Pencemaran memiliki prinsip pendugaan untuk mengetahui tingkat pencemaran secara relatif terhadap parameter kualitas air tertentu (Angraheni, 2015).

Hasil analisis yang telah dilakukan dengan menggunakan indeks pencemaran didapat rata-rata nilai IP sebesar 3.4347. Meskipun tergolong tercemar ringan tetapi pada beberapa stasiun didapatkan nilai IP yang lebih tinggi dari rata-ratanya yaitu stasiun 1,2,3,4 dan 6. Nilai IP tertinggi pada lokasi penelitian di Danau Buyan berada di stasiun 4 dengan nilai 3.8673. Parameter yang memiliki nilai IP $>1$ (tercemar) di stasiun 4 lokasi pengamatan adalah Ammonia (4.5654), Nitrat (4.7857), BOD (3.5190), COD (1.1916), dan Sulfida (2.3359). Hal ini dikarenakan pada stasiun pengamatan 4 memiliki 
jarak yang cukup dekat dengan KJA yang ada di Danau Buyan yaitu sejauh 150 meter kearah timur KJA. Stasiun 4 juga merupakan stasiun terdekat dengan lahan pertanian dan pemukiman masyarakat. Tingginya nilai Ammonia, Nitrat, BOD, COD dan Sulfida juga disebabkan oleh akumulasi dari beberapa limbah pencemar yang berasal dari sisa pakan KJA, limbah masyarakat sekitar, dan aktifitas pertanian yang berada di sekitar Danau Buyan. Lokasi stasiun pengamatan 4 yang dekat dengan areal pertanian dan pemukiman menyebabkan masuknya buangan limbah domestik yang mengandung ammonia ke perairan Danau Buyan. Hal ini akan menyebabkan konsentrasi nitrat ikut tinggi dan tersebar ke beberapa stasiun pengamatan lainnya karena adanya faktor arus yang digerakkan oleh angin. Meskipun terdapat perbedaan status pencemaran berdasarkan hasil analisis indeks STORET dan Indeks Pencemaran. Namun pada kedua metode tersebut stasiun pencemaran terendah yaitu pada stasiun pengamatan 6 (-74 dan 2.5498). Nilai pencemaran yang rendah pada stasiun pengamatan 6 dapat disebabkan oleh pada stasiun pengamatan 6 masukan bahan pencemar hanya berasal dari limbah KJA dan tumbuhan air. Pada stasiun pengamatan 6 tidak dipengaruhi oleh limbah pertanian dan pemukiman.

Nilai pencemaran di stasiun pengamatan kontrol tergolong cukup tinggi (IP : 3,3968 dan Indeks STORET -74) dan terdapat 4 parameter (ammonia, nitrat, BOD dan sulfida) yang melibihi ambang baku mutu. Hal ini disebabkan pada saat pengamatan ditemukan banyak tumbuhan air kiambang (Pastia stratiodes) di stasiun kontrol. Adanya tumbuhan air ini secara tidak langsung akan mempengaruhi nilai parameter fisik dan kimia kualitas air yang diukur. Sesuai dengan yang dinyatakan oleh Kovaks (1992), bahwa tingginya kehadiran tumbuhan air di dalam suatu perairan baik yang sejenis ataupun berbeda jenis menandakan daerah tersebut memiliki tingkat kesuburan tinggi dan dapat terjadi eutrofikasi. Tumbuhan air yang membusuk akan meningkatkan bahan pencemar di Danau Buyan. Hal ini karena daun kiambang yang membusuk mempunyai kandungan $\mathrm{N}$ dan $\mathrm{P}$ yang tinggi. Pada penelitian yang telah dilakukan daun kiambang mengandung $\mathrm{N}$ sebesar 0,216 mg/l dan $\mathrm{P}$ sebesar $0,054 \mathrm{mg} / \mathrm{l}$. Sedangkan pada akar mempunyai kandungan $\mathrm{N}$ sebesar 0,073 mg/l dan kandungan P sebesar 0,021 $\mathrm{mg} / \mathrm{l}$ (Angga $d k k ., 2010$ ). Pengaruh arus yang cukup sedang di perairan Danau Buyan juga membawa bahan pencemar yang berasal dari KJA maupun limbah pertanian terbawa hingga ke titik kontrol. Hal ini dikarenakan arus air di danau dapat bergerak ke berbagai arah (Effendi, 2003).

Pada Danau Buyan bahan pencemar pada umumnya berasal dari limbah domestik, pertanian, ataupun sisa pakan yang tidak termakan sangat mudah terakumulasi karena rendahnya kecepatan pergantian air. Untuk mencegah semakin rendahnya status mutu kualitas air di perairan Danau Buyan perlu dilakukan upaya pengelolaan lingkungan perairan. Upaya perbaikan manajemen perikanan di Danau Buyan yang dapat dilakukan diantaranya yaitu :

a. Perlu dilakukan peninjauan kembali berdasarkan hasil pengukuran kualitas air yang telah dilakukan dalam pengembangan Keramba Jaring Apung (KJA) yang ada di Danau Buyan. Tidak hanya fokus di satu lokasi saja.

b. Penggunaan pakan alami (Azolla Microphylla) pada KJA di Danau Buyan. Tanaman azolla merupakan gulma air yang tidak termanfaatkan, tetapi memiliki kandungan protein yang cukup tinggi, yaitu $28,12 \%$ berat kering (Handajani, 2000). Selama ini KJA di Danau Buyan sepenuhnya menggunakan pakan pellet. Penggunaan pakan alami pada KJA Danau Buyan dapat mengurangi $>50 \%$ sisa pakan pellet yang masuk ke perairan Danau Buyan khususnya pada stasiun pengamatan 1 , 2 dan 3.

c. Karena tumbuhan air mendukung keberadaan bahan organik dengan kecepatan perkembangan tumbuhan air yang sedemikian cepat. Menyebabkan bahan organik yang berada di badan Danau Buyan semakin buruk. Maka perlu dilakukan pembersihan tumbuhan air di Danau Buyan tidak hanya pada wilayah Utara (Stasiun Pengamatan 1, 2, \& 3). Tetapi juga pada wilayah Timur (Stasiun Pengamatan 4 \& 5) dan wilayah Barat (Stasiun Pengamatan 6 \& 7).

d. Berdasarkan hasil pengukuran bahwa BOD, $\mathrm{COD}, \mathrm{H}_{2} \mathrm{~S}$, Phosfat, Ammonia dan Nitrat yang tinggi berasal dari pertanian. Maka perlu mengurangi limbah pertanian dengan cara menghindari penggunaan pupuk dan insektisida yang berlebihan. Penggunaan pupuk kandang yang tidak terkontrol akan menyebabkan pencemaran organik yang masuk ke badan perairan wilayah Utara (Stasiun pengamatan 1, 2 dan 3) dan Barat (stasiun pengamatan 6 dan 7) Danau Buyan.

\section{KESIMPULAN DAN SARAN}

\subsection{KESIMPULAN}

Penilaian status pencemaran perairan di Danau Buyan berdasarkan metode Indeks STORET dan Indeks Pencemaran tergolong dalam kategori tercemar berat dan tercemar ringan. Skor rata-rata Indeks STORET yang didapat sebesar -82 dengan nilai terburuk sebesar -98 (stasiun 3). Status pencemaran yang tergolong tercemar berat ini disebabkan oleh terdapat 7 parameter (kekeruhan, $\mathrm{pH}$, ammonia, 
nitrat, BOD, COD, dan sulfida) yang melebihi ambang baku mutu kualitas air di Danau Buyan. Skor rata-rata Indeks Pencemaran yang didapat sebesar 3.4347 dengan nilai tertinggi sebesar 3.8673 (stasiun 4). Status pencemaran yang tergolong tercemar ringan ini disebabkan oleh 5 parameter (ammonia, nitrat, BOD, COD, dan sulfida) yang melebihi ambang baku mutu kualitas air di Danau Buyan. Pada kondisi tersebut pengaruh KJA, pertanian dan aktivitas lainnya memberikan beban berat terhadap perairan di Danau Buyan. Hal ini ditunjukkan dengan tingginya nilai parameter kekeruhan, $\mathrm{pH}$, ammonia, nitrat, BOD, COD dan sulfida dari hasil pengukuran yang telah dilakukan. Saran pengelolaan terhadap Danau Buyan dalam usaha perbaikan kualitas perairan yaitu dengan melakukan peninjauan kembali dalam pengembangan KJA yang ada di Danau Buyan, penggantian sebanyak $>50 \%$ pellet dengan pakan alami, melakukan pembersihan tumbuhan air Kiambang (Pastia stratiodes) di bagian Utara, Timur dan Barat Danau Buyan serta meminimalkan penggunaan pupuk dan insektisida pada lahan pertanian. Jika berdasarkan wilayah stasiun pengamatan maka yang menjadi wilayah tercemar adalah wilayah Utara (Stasiun 1, 2 dan 3) dan Timur (Stasiun 4 dan 5). Selain dekat dengan KJA wilayah Utara dan Timur juga dekat dengan lahan pertanian, jadi mendapat masukan bahan pencemar lebih banyak dibandingkan dengan wilayah Barat (Stasiun 6 dan 7).

\subsection{SARAN}

Mengacu pada kesimpulan, pengembangan KJA di Danau Buyan harus dilakukan berdasarkan pendekatan daya dukung perairan. Kalaupun sangat strategis harus mengembangkan Keramba Jaring Apung di Danau Buyan maka dibatasi jumlahnya dan zonasinya harus sesuai. Pemerintah, stakeholder dan masyarakat harus mengembangkan pertanian berbasis organik atau sistem pertanian terpadu untuk mengurangi beban pencemaran di Danau Buyan.

\section{DAFTAR PUSTAKA}

Angga, R.Muh, Salsabiela, Wahyu Mei S, Yuyun Indriana dan Anggun Rina. 2010. Kajian Biologi Gulma Mengenai Berbagai Macam Kandungan dan

PemanfaatanGulmaKiyambang.http: / / www.slideshare.net/RMABP_Permadi/biologigulma-gulma-kiambang. Diakses tanggal 13 Juli 2016.

Anggoro, S. 1996. Dampak Pencemaran terhadap Fisik-Kimia Air. Materi Kursus AMDAL. Pusat Penelitian Lingkungan Hidup (PPLH) UNDIP. Semarang. 1 (1) : 103.
Angraheni,W. 2015. Status Pencemaran Perairan Pesisir Tanjung Pasir,Kabupaten Tangerang, Banten.(Skripsi).Fakultas Kelautan dan Ilmu Perikanan. Institut Pertanian Bogor.Bogor

[BLH]-Badan Lingkungan Hidup Provinsi Bali. 2010. Kelestarian Danau Buyan Kabupaten Buleleng Provinsi Bali. Poster Online BLH Bali. Hal : 2.

[BPS]-Badan Pusat Statistik Provinsi Bali. 2010. Bali dalam Angka. Katalog BPS No.1102001.51: 465p.

Barus, T. A. 2004. Pengantar Limnologi, Studi Tentang Ekosistem Sungai dan Danau.(Skripsi). Jurusan Biologi Fakultas MIPA. Universitas Sumatra Utara.Medan

Connel, D. W. dan Miller, G. J. 1995. Kimia dan Otoksikologi Pencemaran. Cetakan Pertama. Jakarta: Universitas Indonesia. 2 (1) : 93.

Djokosetiyanto, D., A. Sunarman dan Widanarni. 2006. Perubahan Ammonia (NH3-N), Nitrit (NO2-N) dan Nitrat (NO3-N) pada Media Pemeliharaan Ikan Nila Merah (Oreochromis sp.) di dalam Sistem Resirkulasi. Jurnal Akuakultur Indonesia. 5 (1) : 13-20.

Effendi, H. 2003. Telaah Kualitas Air Bagi Pengelolaan Sumber Daya dan Lingkungan Perairan. Kanisius. Yogyakarta. 249 hal.

Erlania, Rusmaedi, A.B. Prasetio, J. Haryadi. 2010. Dampak Manajemen Pakan dari Kegiatan Budidaya Ikan Nila (Oreochromis niloticus) di Keramba Jaring Apung Terhadap Kualitas Perairan Danau Maninjau. Prosiding Forum Inovasi Teknologi Akuakultur. Tanjung Raya. Diakses tanggal 12 Juli 2016

Ginting, O. 2011. Studi Korelasi Kegiatan Budidaya Ikan Keramba Jaring Apung dengan Pengayaan Nutrien (Nitrat dan Fosfat) dan Klorofil-a di Perairan Danau Toba. Jurnal Perikanan. 1 (2) : 4-25.

Goldman, C.R. and A.J. Horne, 1983. Limnology. McGraw Hill Book Company.New York. 464 pages.

Handajani, 2000. Peningkatan Kadar Protein Tanaman Azolla Microphylladengan Mikrosimbion Anabaena Azollae dalam Berbagai Konsentrasi N dan P yang Berbeda pada Media Tumbuh.(Tesis). Program Program Pascasarjana Institut Pertanian Bogor.Bogor

Halwart, M., Soto, D., \& Arthur, J.R. 2007. Cage aquaculture-regional reviews and global overview. FAO fisheries technical paper.241 pages.

Jenie. B.S.L \& W.P. Rahayu. 1993. Penanganan Limbah Industri Pangan: Kanisius. Yogyakarta.172 hal 
Kartamihardja E.S., 2008, Perubahan Komposisi Komunitas Ikan dan Faktor Faktor Penting yang Mempengaruhi selama 40 Tahun Umur Waduk Djuanda. Jurnal Iktiologi Indonesia. 2 (3) : 13.

Kordi, M. G dan Tancung A. B., 2005. Pengelolaan Kualitas air. Penerbit Rineka Cipta. Jakarta. 208 hal.

Kovaks, M. 1992. Biological indicators in environmental protection. Ellis Horwood Liimited, England.155 pages

Maniagasi, Richard. Sipriana S. Tumembouw, Yoppy Mundeng. 2013. Analisis kualitas fisika kimia air di areal budidaya ikan Danau Tondano Provinsi Sulawesi Utara. Jurnal Budidaya Perairan. 1 (2) : 12-13.

Margonof, 2007. Model Pengendalian Pencemaran Perairan di Danau Maninjau Sumatera Barat. (Tesis). Pascasarjana. Institut Pertanian Bogor.Bogor
Nastiti, A.S., Krismono, \& Kartamihardja, E.S. 2001. Dampak Budidaya Ikan dalam Keramba Jaring Apung Terhadap Peningkatan Unsur N dan P di Perairan Waduk Saguling, Cirata, dan Jatiluhur. Jurnal Penelitian Perikanan. Indonesia, Pusat Riset Perikanan Budidaya. Jakarta, 7(2): 22-30.

Odum, E, P. 1994. Dasar-Dasar Ekologi. Terj. T. Samingan \& B. Sriganono Yogyakarta : Edisi ketiga. Gajah Mada University-Press. Hal 412.

Odum, E. P. 1996. Dasar - Dasar Ekologi. Gadjah Mada University Press. Yogyakarta. Hal 341.

Pemerintah Republik Indonesia, 2001. Peraturan Pemerintah Nomor 82 tahun 2001 Tentang Pengelolaan Kualitas Air dan Pengendalian Pencemaran Air. Jakarta.

Sunarto. 2003. Peranan Dekomposisi dalam Proses Produksi pada Ekosistem Laut, Institut Pertanian Bogor. Bogor. 98 hal. 